\begin{tabular}{|c|c|c|}
\hline & Int.J.Curr.Microbiol.App.Sci (2021) 10(08): 556-564 & \\
\hline & $\begin{array}{l}\text { International Journal of Current Microbiology and Applied Sciences } \\
\text { ISSN: 2319-7706 Volume } 10 \text { Number } 08 \mathbf{( 2 0 2 1 )} \\
\text { Journal homepage: http://www.ijcmas.com }\end{array}$ & $=0$ \\
\hline $\begin{array}{l}\text { EXCELLENT } \\
\text { PUBLISHERS }\end{array}$ & & www.ijcmas.com \\
\hline
\end{tabular}

\title{
Assessment and Prioritization of Information Needs of Pashusakhis from Parbhani District of Maharashtra for Development of IT-Enabled Need based Dairy Advisory System
}

\author{
M. S. Pande*, A. P. Patil, D. S. Deshmukh and V. K. Munde \\ College of Veterinary and Animal Sciences, Parbhani, India \\ *Corresponding author
}

Keywords

Information Needs, Pashusakhis, Dairy Advisory System

Article Info

Accepted:

25 July 2021

Available Online:

10 August 2021

\section{A B S T R A C T}

Assessing information needs and their prioritization is an important prerequisite in development of IT-enabled dairy advisory system for stakeholders, including Pashusakhis. Pashusakhi model is a community-led livestock extension service. The role of Pashusakhi centres around counselling services for disease prevention and sharing of good management practices among the farmers. Thus, it raised the need for developing IT-enabled dairy advisory system for Pashusakhis in order to update their technical knowledge and skill, with self-paced learning, revising and resolving queries by their own. Assessment of information needs on dairying expressed by Pashusakhis prioritized, animal health and care (Weighted Mean Score - 2.45) as the most needed area, followed by general management practices (2.36), feeding management (2.35), breeding management (2.33), marketing management (2.33) and housing management (2.28).

\section{Introduction}

Dairying is one of the important income generation and nutriment sources for rural, peri-urban and urban communities as well. Most of the milk produced comes from the non-organized sector. Pashusakhi being an alternative livestock extension service provider, serves the livestock in her area under coverage by coherence with farmers, preventive and primary health measures to livestock. Pashusakhis are also trained to take up entrepreneurial activities to meet the demand locally (http://vikaspedia.in). Nevertheless, to work in an efficient way, Pashusakhi is supposed to know the basics and advancement in animal husbandry sector. Assessing information needs of Pashusakhis on animal husbandry will also help to inform them in more profound way, which will 
ultimately be beneficial to the dairy farmers. Thus, a study was conducted to assess and prioritize information needs of Pashusakhis in Parbhani district of Maharashtra state on dairy farmingfor developing IT-enabled dairy advisory system.

\section{Materials and Methods}

A total of 120 Pashusakhis from seven Community Managed Resource Centers (CMRCs) from Mahila Arthik Vikas Mahamandal (MAVIM), Parbhani district in Maharashtra state, were selected purposively as respondents for the present study.

A structured interview schedule with threepoint continuum scale was developed after a thorough discussion with experts. The pilot survey was conducted and data so generated, was pre-tested before the actual survey.Considering the then COVID-19 pandemic situation, all necessary measures were followed, also during the during unlock phase as per guidelines from the Government to maintain good health status at both researcher and respondents' ends.

The schedule comprised of six major areas of management in dairying viz., housing, breeding, feeding, general management practices, health and care and marketing. Early mentioned areas of dairying comprised of set of direct questions with their responses ranked as 3,2 and 1; where 3impliedas the 'most needed', 'needed' and 'not needed' respectively. Classification was done on the basis of Weighted Mean Score (WMS) for each question and every area (Subhash et al., 2015).

\section{Results and Discussion}

Responses were recorded and analyzed to assess information needs of Pashusakhis over important areas in dairy farming including housing, breeding, feeding, general management practices, health and care; as well as marketing.

\section{Information needs on health and care}

Distribution of respondents according to their information needs on several aspects under the topic health and care of dairy animals is shown in Table 1.

$70 \%$ Pashusakhis felt information on care to be taken during vaccination as the most needed, followed by vaccination schedule $(59.16 \%)$, disposal of carcass $(42.5 \%)$ and signs of sick animal (21.16\%) respectively.

Vaccination failure due to poor maintenance of cold chain till vaccination in remote interior places might be causing distrust among clientele groups and may also risk valuable dairy animals for infections. As care measures to be adopted during vaccination is technical and important area, it may be therefore, a significant number of Pashusakhis (70\%) sought it as the most needed segment for seeking information.

Infections may cause diverse losses, impeded development, declined production, mortality, medical expenditure and consulting services and in this way prompts substantial financial misfortunes. Prevention is the best alternative for reducing disease-related casualties. Pashusakhis might have witnessed this and have tried to update their knowledge on vaccination and care.

Gangil (2019) experienced similar results where knowledge about disease symptoms was the topic on which information was mostly needed by respondents. Outcomes from study of Jadeja (2018) are in also line with present study as 'health practices' was the most preferred for information needs by rural women with 17.76 as mean score. 
Information needs on general management practices

It was observed that a considerable number of Pashusakhis (60.83\%) have expressed their need for information on identification methods of animal (Table 2).

It was also recorded that, Pashusakhis were not that much familiar with identification of age by dentition pattern of dairy animals.

Pashusakhis might have opined that, information on animal identification methods and record-keeping as mostly needed in management area, since animal identification is also important for insurance, while recordkeeping carries its own significance from the management decision point of view.

Beri (2008) noted that $73.64 \%$ of respondents expressed information on care and management of calves as the most needed one.

\section{Information needs on feeding management}

Observations from the study over information needs on feeding management of dairy animals by Pashusakhis revealed that, information on the topics like hydroponic technology (70.84\%), azolla (67.5\%) and method for feed processing and enrichment (58.34\%) were mostly needed by Pashusakhis (Table 3).

This might be because of the reason that, techniques like hydroponic and alternative feed resources like azolla are comparatively new invogue and might not be that much seen by Pashusakhis as adopted and practised by farmers at the grass root level. $51.66 \%$ of Pashusakhis expressed their high need of information on silage making, feeding practices and their benefits. $65 \%$ respondents were found to have medium level of information needs on balanced ration.
These figures find similarity to that of $\mathrm{S}$ Subhash et al., (2015), where it was noted that, $60 \%$ of respondents listed information on feeding schedule as mostly needed, followed by balanced ration $(51.7 \%)$.

\section{Information needs on animal breeding}

As per the information needs expressed by Pashusakhis on breeding management of dairy animals, breeds of cattle for dairy farming was opted as the most needed segment (69.16\%), followed by merits of artificial insemination $(66.67 \%)$, time of $\mathrm{AI}$ or natural service $(48.34 \%)$ and breeds of buffalo (55\%). Information need on gestation period in dairy animals was found to be the least needed information area (06.67) under breeding management (Table 4).

Observations on breeding management might be recorded with more requirement of information needs on breeds of cattle for dairy farming (69.16\%), merits and time of AI or natural service (66.67\%) etc., since significant number of farmers involved in dairy farming are many a times seen more interested in acquiring information on high milk yielding animal breeds and effective breeding strategies for enhanced milk production.

The results are in line with observations reported by Singh et al., (2020) that training needs for selection of breeds was ranked first by the respondents under breeding management section.

\section{Information needs on marketing management}

It was clearly expressed that $72.50 \%$ Pashusakhis felt marketing channels as the most needed information area under marketing, followed by expression of $52.50 \%$ respondents on packaging methods and $43.33 \%$ on government schemes regarding 
dairy farming. $62.50 \%$ respondents Pashusakhis felt the information need on insurance policies for dairy animals, whereas $13.33 \%$ of interviewees expressed information on value added milk products as the most needed (Table 5).

The probable reasons for these outcomes might be so because, most of them were still needed to know more information about marketing channels of milk, since much of the milk is either sold loose or directly to the dairy co-operatives. So, limited range of milk products are prepared in lesser quantities without proper packaging, most of the times. Marketing of milk is usually got overlooked by people involved in dairy farming. However, a Pashusakhi is expected to know entrepreneurship-driven things like marketing channels, value added milk products, packaging of milk and milk products and government schemes etc.

Results from Singh et al., (2015) slightly differs from present study, where it was noted that, majority of farmers (70.58 per cent) needed information on different subsidy schemes of the Government.

\section{Information needs on housing management}

As regards to housing management, types of housing $(46.66 \%)$ and criteria for site selection of dairy farm $(36.66 \%)$ were the two major concerns on which information was highly needed. Type of floor, roof and farm waste were described as the information need by $36.66 \%, 35.83 \%$ and $30.83 \%$ of the Pashusakhi respondents (Table 6).

These results might appear so, because housing management is one of the important areas in dairy farm establishment and
Pashusakhis may be having first-hand information on basics of housing management. However, selection of site is crucial, yet often deserted issue; Pashusakhis marked this as an important aspect on which they wish to seek information.

Singh et al., (2020) reported similar findings where construction and proper design of cattle shed were topics expressed by farm women as the most needed with 74.17 and 66.94 as training need indices, respectively.

\section{Priortisation of information needs on dairy farming according to their Weighted Mean Score}

Information needs on management related aspects of dairy farming expressed by Pashusakhis as respondents were prioritised with assigning ranks under prevailing study. Ranking was based on weighted mean score of each area and calculated separately according to the responses from interviewees.

Health and care stood first i.e., highly needed with WMS 2.45 (rank I), followed by General Management Practices (WMS 2.36, rank II), feeding management (WMS 2.35., rank III),breeding and marketing management (WMS 2.33, rank IV), while the housing management was ranked fifth, with 2.28 as its weighted mean score.

Singh et al., (2019) described similar kind of results in their study, where it was mentioned that information on healthcare management was highly required by respondents followed by fodder production and management, general management, nutrition and feeding and lastly breeding and reproduction with weighted mean score (WMS) 2.32, 2.29, 2.14, 2.09 and 1.90 respectively. 
Table.1 Distribution of respondents according to their information need on health andcare

\begin{tabular}{|l|c|c|c|c|}
\hline \multirow{2}{*}{$\begin{array}{l}\text { Sr. } \\
\text { No. }\end{array}$} & Categories & \multicolumn{3}{|c|}{ Frequency (Per cent) } \\
\cline { 3 - 5 } & & Most needed & Needed & Not needed \\
\hline \multicolumn{5}{|c|}{ (I) Health and care } \\
\hline 1. & Signs of sick animal & $35(21.16)$ & $71(59.16)$ & $14(11.66)$ \\
\hline 2. & Vaccination schedule & $71(59.16)$ & $47(39.16)$ & $02(01.66)$ \\
\hline 3. & Care during vaccination & $84(70.00)$ & $30(25.00)$ & $06(05.00)$ \\
\hline 4. & Disposal of carcass & $51(42.50)$ & $66(55.00)$ & $03(02.50)$ \\
\hline
\end{tabular}

*Percentage is given in parenthesis

Table.2 Distribution of respondents according to their information needs on general management practices

\begin{tabular}{|c|c|c|c|c|}
\hline \multirow{2}{*}{$\begin{array}{l}\text { Sr. } \\
\text { No. }\end{array}$} & \multirow[t]{2}{*}{ Categories } & \multicolumn{3}{|c|}{ Frequency (Per cent) } \\
\hline & & Most needed & Needed & Not needed \\
\hline \multicolumn{5}{|c|}{ (II) General management practices } \\
\hline 1. & Animal identification methods & $73(60.83)$ & $43(35.83)$ & $04(03.33)$ \\
\hline 2. & Identification of age by dentition & $65(54.16)$ & $32(26.66)$ & $23(19.16)$ \\
\hline 3. & Record keeping & $61(50.84)$ & $53(44.16)$ & $06(05.00)$ \\
\hline 4. & Isolation of animals & $33(27.50)$ & $76(63.33)$ & $11(09.16)$ \\
\hline 5. & Other scientific management practices & $42(35.00)$ & $71(59.16)$ & $07(05.83)$ \\
\hline 6. & Calf management & $55(45.84)$ & $50(41.66)$ & $15(12.50)$ \\
\hline
\end{tabular}

*Percentage is given in parenthesis

Table.3 Distribution of respondents according to their information needs on feeding

\begin{tabular}{|c|c|c|c|c|}
\hline \multirow{2}{*}{$\begin{array}{l}\text { Sr. } \\
\text { No. }\end{array}$} & \multirow[t]{2}{*}{ Categories } & \multicolumn{3}{|c|}{ Frequency (Per cent) } \\
\hline & & Most needed & Needed & Not needed \\
\hline \multicolumn{5}{|c|}{ (III) Feeding } \\
\hline 1. & Fodder crop cultivation & $54(45.00)$ & $63(52.50)$ & $03(02.50)$ \\
\hline 2. & Oilseed cakes & $34(28.34)$ & $74(61.66)$ & $12(10.00)$ \\
\hline 3. & $\begin{array}{l}\text { Feed processing and } \\
\text { enrichment methods }\end{array}$ & $70(58.34)$ & $45(37.50)$ & $05(04.16)$ \\
\hline 4. & Azolla production & $81(67.50)$ & $38(31.66)$ & $01(00.84)$ \\
\hline 5. & Hydroponic & $85(70.84)$ & $30(25.00)$ & $05(04.16)$ \\
\hline 6. & Silage making & $62(51.66)$ & $52(43.34)$ & $06(05.00)$ \\
\hline 7. & $\begin{array}{l}\text { Dry matter requirement for } \\
\text { maintenance }\end{array}$ & $57(47.50)$ & $57(47.50)$ & $06(05.00)$ \\
\hline 8. & Balanced ration & $22(18.34)$ & $78(65.00)$ & $20(16.66)$ \\
\hline 9. & Water requirement & $26(21.66)$ & $68(56.66)$ & $26(21.66)$ \\
\hline 10. & Ingredients of concentrates & $39(32.50)$ & $79(65.83)$ & $02(01.66)$ \\
\hline 11. & Benefits of fodder chaffing & $37(30.83)$ & $75(62.50)$ & $08(06.67)$ \\
\hline
\end{tabular}

*Percentage is given in parenthesis 
Table.4 Distribution of respondents according to their information needs on animal breeding

\begin{tabular}{|l|c|c|c|c|}
\hline \multirow{2}{*}{$\begin{array}{l}\text { Sr. } \\
\text { No. }\end{array}$} & Categories & \multicolumn{3}{|c|}{ Frequency (Per cent) } \\
\cline { 2 - 4 } & & Most needed & Needed & Not needed \\
\hline 1. & & $48(40.00)$ & $61(50.83)$ & $11(09.17)$ \\
\hline 2. & Signs of estrous & $66(55.00)$ & $51(42.50)$ & $03(02.50)$ \\
\hline 3. & Breeds of buffalo & $83(69.16)$ & $36(30.00)$ & $01(00.84)$ \\
\hline 4. & Breeds of cattle & $39(32.50)$ & $67(55.83)$ & $14(11.67)$ \\
\hline 5. & Estrous cycle & $08(06.67)$ & $81(67.50)$ & $31(25.83)$ \\
\hline 6. & Testation period & $58(48.34)$ & $47(39.16)$ & $15(12.50)$ \\
\hline 7. & Exotic cow breeds & $26(21.66)$ & $88(73.34)$ & $06(05.00)$ \\
\hline 8. & Merits of AI & $80(66.67)$ & $36(30.00)$ & $04(03.34)$ \\
\hline
\end{tabular}

*Percentage is given in parenthesis

Table.5 Distribution of respondents according to their information needs on marketing management

\begin{tabular}{|l|c|c|c|c|}
\hline \multirow{2}{*}{$\begin{array}{l}\text { Sr. } \\
\text { No. }\end{array}$} & \multicolumn{2}{|c|}{ Categories } & \multicolumn{3}{|c|}{ Frequency (Per cent) } \\
\hline \multicolumn{5}{|c|}{$(\mathbf{V})$ Marketing management } \\
\hline 1. & \multicolumn{2}{|c|}{ Needed } & Not needed \\
\hline 2. & Marketing channels & $87(72.50)$ & $30(25.00)$ & $03(02.50)$ \\
\hline 3. & Packaging methods & $63(52.50)$ & $54(45.00)$ & $03(02.50)$ \\
\hline 4. & Government schemes & $52(43.33)$ & $61(50.83)$ & $07(05.83)$ \\
\hline 5. & Animal insurance & $36(30.00)$ & $75(62.50)$ & $09(07.50)$ \\
\hline
\end{tabular}

*Percentage is given in parenthesis

Table.6 Distribution of respondents according to their information needs on housing

\begin{tabular}{|l|c|c|c|c|}
\hline \multirow{2}{*}{$\begin{array}{c}\text { Sr. } \\
\text { No. }\end{array}$} & Categories & \multicolumn{3}{|c|}{ Frequency } \\
\hline \multicolumn{4}{|c|}{ (I) Housing } \\
\hline 1. & Selection of site for dairy farm & $44(36.66)$ & $71(59.16)$ & $05(04.16)$ \\
\hline 2. & Type of housing & $56(46.66)$ & $58(48.34)$ & $06(05.00)$ \\
\hline 3. & Type of floor & $44(36.66)$ & $63(52.50)$ & $13(10.84)$ \\
\hline 4. & Type of roof & $43(35.83)$ & $71(59.17)$ & $06(05.00)$ \\
\hline 5. & Type of farm waste & $37(30.83)$ & $68(56.67)$ & $15(12.50)$ \\
\hline 6. & Management of farm waste & $37(30.83)$ & $70(58.33)$ & $13(10.83)$ \\
\hline
\end{tabular}

*Percentage is given in parenthesis 
Fig.1
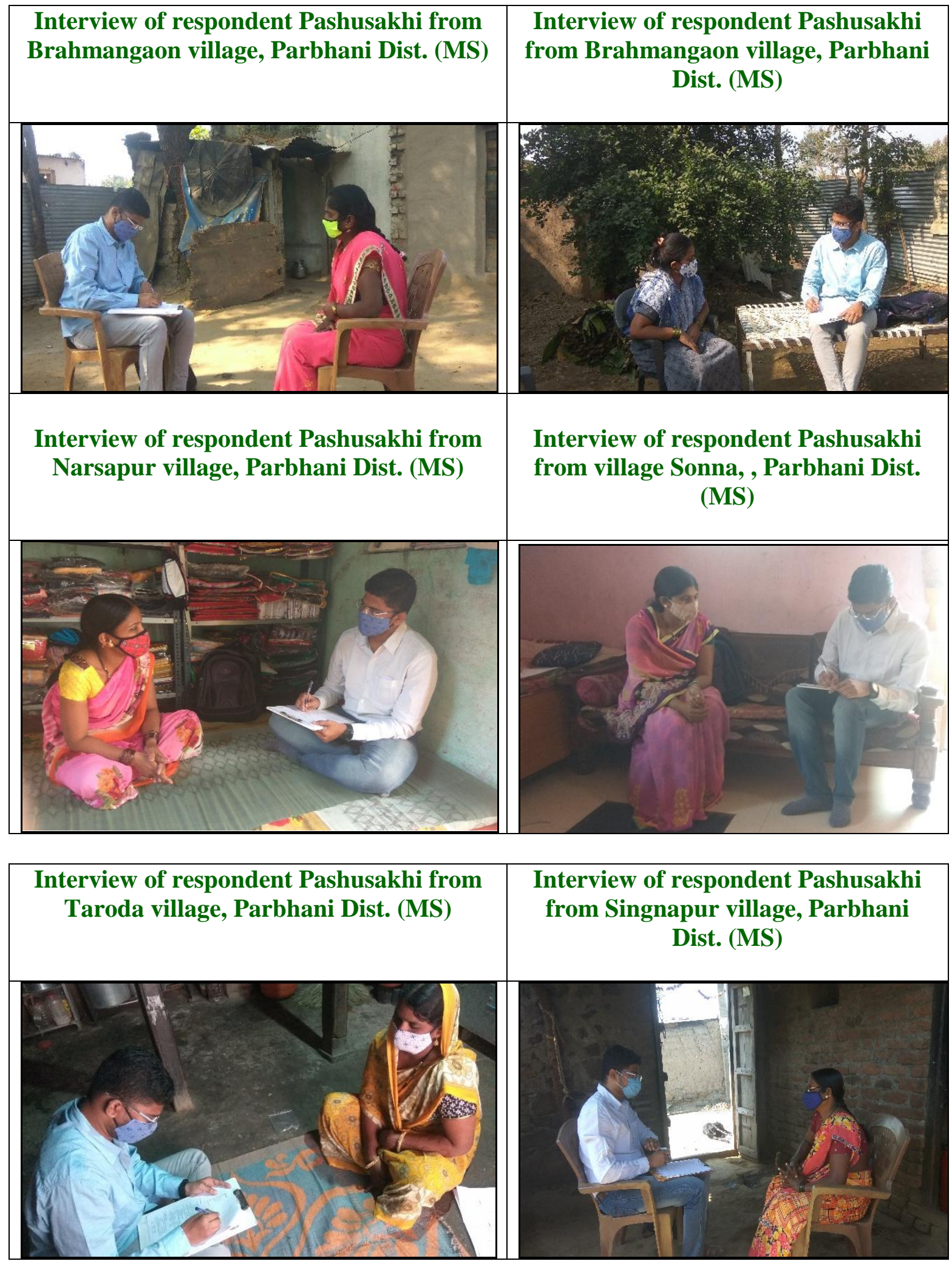
Table.7 Distribution of areas of information needs on dairy farming according to their Weighted Mean Score

\begin{tabular}{|c|c|c|c|}
\hline Sr. No. & Area & WMS & Rank \\
\hline $\mathbf{1}$ & Health and Care & 2.45 & I \\
\hline $\mathbf{2}$ & General managemental practices & 2.36 & II \\
\hline $\mathbf{3}$ & Feeding Management & 2.35 & III \\
\hline $\mathbf{4}$ & Breeding Management & 2.33 & IV \\
\hline $\mathbf{5}$ & Marketing management & 2.33 & IV \\
\hline $\mathbf{6}$ & Housing management & 2.28 & V \\
\hline
\end{tabular}

Interviewing Pashusakhis revealed that health and care of dairy animals was the most needed information area, followed by general management practices and feeding management. Housing management was recognized as the least information needed area expressed by majority of the respondents under the survey. This assessment and prioritisation of the information needs is an important prerequisite in developing ITenabled need based dairy advisory system. Further, the study can also be considered as foundation in designing training modules for Pashusakhis.

\section{References}

Babu Beri, 2008. Information Needs of Women Self Help Groups (WSHGs) Involved in Dairy Farming for Capacity Building, M.V.Sc. Thesis, Submitted to Sri Venkateswara Veterinary University Tirupati - 517502 (A.P.) India.

Gangil, Deepak, 2019. Assessment of short message advisory service developed for the dairy farmers of Punjab, Ph.D. Thesis, Submitted to, Guru Angad Dev Veterinary and Animal Sciences University, Ludhiana.

Jadeja K. M., 2018. Extent of Information Needs About Animal Husbandry Practices by The Farm Women of Rajkot District, M.Sc. Thesis, Submitted to, JAU, Junagadh.

Ritu Bala, 2016. Knowledge and Training Needs of Farm Women Regarding Dairy Farming Practices in Bikaner District of Rajasthan, M.Sc. Thesis, Submitted to, Swami Keshwanand Rajasthan Agricultural University, Bikaner College of Home Science, Bikaner.

S Subhash, Jancy Gupta, G Prasad Babu, 2015. Information Needs Assessment and Prioritization of Dairy Farmers. Journal Krishi Vigyan 2015, 4(1): 5155.

Singh Bacchu, Deepa Indoria, K. C. Meena and G. S. Meena, 2020. Training Needs of Tribal Farm Women in Dairy Farming in Eastern Rajasthan. Int. J. Curr. Microbiol. App. Sci. 9(05): 33023305.

Singh J., Kumar P. \& Singh A., 2019. Dissemination of information to dairy farmers in Jammu and Kashmir: Developing a web module. Information Development. Available from https://journals.sagepub.com/ doi/abs/10.1177/0266666919884349.

Singh N., Malhotra P. and Singh J., 2015. Information needs and seeking behaviour of dairy farmers of Punjab. Indian J Dairy Sci. 69(1) 98-104. Available from https://www.researchgate.net/publicatio n/294088428 (http://vikaspedia.in) 


\section{How to cite this article:}

Pande, M. S., A. P. Patil, D. S. Deshmukh and Munde, V. K. 2021. Assessment and Prioritization of Information Needs of Pashusakhis from Parbhani District of Maharashtra for Development of IT-Enabled Need based Dairy Advisory System. Int.J.Curr.Microbiol.App.Sci. 10(08): 556-564. doi: https://doi.org/10.20546/ijcmas.2021.1008.066 